custom solutions professional military problems and improving the skills of professional communication.

The article reveals the essential content of the application of active learning methods. Found that it enables the future masters of military-social management to engage in purposeful process of development in their creative thinking that will professionally perform their tasks.

Key words: innovative technologies of teaching; educational-cognitive activity; communicative-dialogue technology; informational technology; masters.

УДК 378.14.015.62

Володимир Оліферук, Національний університет оборони України імені Івана Черняховського, м. Київ

ORCID ID 0000-0002-0722-7561

DOI: $10.33099 / 2617-1775 / 2019-02 / 138-147$

\title{
ВИЗНАЧЕННЯ КРИТЕРІЇВ ОЦІНЮВАННЯ ПРОФЕСІЙНОЇ КОМПЕТЕНТНОСТІ ВИКЛАДАЧА ВВНЗ
}

У статті розглядається проблема визначення критеріїв оцінювання професійної компетентності викладача вищзого військового навчального закладу (далі - ВВНЗ). Наводяться приклади формування структури критеріїв професіоналізму викладача на підставі професійно-освітнього, професійно-діяльнісного, професійноособистісного системних компонентів. Професійна компетентність викладача ВВНЗ визначається як складна структура взаємовідносин $і$ зв'язків елементів, які становлять еталонні критерії професіоналізму.

Ключові слова: критерії; педагогічна діяльність; викладач; професійна компетентність; вищий військовий навчальний заклад.

Постановка проблеми. Вдосконалення педагогічної діяльності викладача ВВН3 в сучасних умовах розвитку Збройних Сил України та системи вищої військової освіти характеризується переходом від репродуктивного рівня виконання професійних дій в освітньому процесі до творчого, інноваційного рівня, ускладненням завдань навчання та виховання тих, хто навчається, підвищенням вимог до професійної компетентності викладача.

Аналіз досліджень 3 проблем освіти дозволяє припустити, що професійна компетентність викладача ВВНЗ визначається не стільки професійними знаннями та навичками, скільки здібністю прогнозувати $\mathrm{i}$ своєчасно вирішувати інноваційні педагогічні завдання, професійно аналізувати та розуміти процеси у сучасному освітньому просторі, напрями і тенденції розвитку освіти, зокрема, військової освіти. Важливе значення мають також особистісні якості викладача, тому що у педагогічної діяльності важко диференціювати особистісні та професійні складові, оскільки вона реалізується через особистісні форми відчуття та розуміння педагогічного процесу. 
Аналіз останніх досліджень і публікацій. $\mathrm{y}$ дослідженнях Ю.П. Азарова, Ю.К. Бабанского, И.В. Грошевої, А.Г. Кузнечової, Н.В. Кузьминої, І.П. Подласого [1-6] та інших відмічається, що педагогічна діяльність має динамічний характер. Під впливом внутрішніх і зовнішніх факторів педагогічна система постійно змінюється, що зумовлює необхідність безперервного розвитку особистості викладача, як важливого компоненту освітньої системи. Згадана особливість спонукає викладача до постійного особистісно-професійного вдосконалення. Актуальним для нашого дослідження $\epsilon$ характеристика поняття “системний підхід” у визначенні критеріїв професійної компетентності викладача. “Системний аналіз - це аналіз руху, що породжує явище, яке складає предмет пізнання, тобто розкриття сутності цих явищ, що включають у себе й самі ці явища" [7, c. 264].

В.Г. Афанасьев визначає цілісну систему як “...сукупність об’єктів, взаємодія яких зумовлює наявність нових інтегральних якостей, не властивих 䛠 складовим компонентам. Компоненти цілісної системи щільно пов'язані між собою, взаємодіють один з одним, вони, так би мовити, інтегровані системою" [8, с. 18-23].

Дослідження цілісної системи передбачає визначення ii якісної специфіки, складу компонентів, що входять до неї, взаємозв'язків, які існують між компонентами. Важливо визначити інтегративні, системоутворюючі фактори, показати внутрішню структуру системи, піi організацію, установити зв'язки системи 3 навколишнім середовищем, 3 іншими системами. У процесі розвитку цілісної системи здійснюється

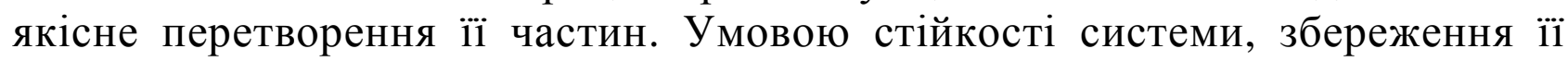
якісної визначеності $\epsilon$ постійний розвиток і поновлення піi складових компонентів. “Об'єкти стають предметом системного дослідження не в емпіричній даності, а на певному теоретичному рівні розглядання, коли утворюється необхідність синтезу системних уявлень, які отримані на різних “зрізах” складного об”єкту” [9, с. 74-78].

Ю.К. Бабанский використовує системний підхід для аналізу процесу навчання. Він стверджує, що основними компонентами процесу навчання, як цілісної системи, $є$ соціально детерміновані цілі навчання, зміст навчання, дидактичні умови, форми і методи діяльності педагогів и тих, хто навчається, аналіз и самоаналіз результатів навчання. "У сучасних умовах назріла необхідність істотного вдосконалення методів педагогічного дослідження i, насамперед, введення в логіку наукового пошуку спеціального аналізу структурних зв'язків об' єкта, що вивчається, $\mathrm{i}$ визначення серед них найбільш істотних, стійких, які відображають відповідні педагогічні закономірності” [10, с. 63].

H.B. Кузьміна визначає педагогічну систему “...як множину структурних i функціональних компонентів, які підпорядковані цілям виховання і навчання підростаючого покоління и дорослих осіб" [11, с. 26]. До структурних компонентів цілісної педагогічної системи вона відносить: 
потреби суспільства (соціально значущі цілі), зміст інформації, що надається, способи досягнення цілей (форми, методи, засоби), контингенти людей, які мають потребу в освіті або у відповідній підготовці, наявність кваліфікованих педагогів.

Кожна педагогічна система може бути розглянута на підставі будьякого із цих компонентів, який у такому випадку виступає, як системоутворюючий. "Функціональні компоненти, - на думку Н.В. Кузьміної, - це стійкі базові зв'язки основних структурних компонентів, що утворюються в процесі діяльності керівників, педагогів, тих, хто навчається, і тим самим забезпечуючи рух, розвиток, вдосконалення педагогічних систем i внаслідок цього їх стійкість, життєздатність" [11, с. 32-40]. Автор також підкреслює “відкритість" педагогічних систем, залежність компонентів системи від впливу зовнішнього середовища.

Таким чином, будь-яка система, у тому числі педагогічна, може розглядатися як відповідним чином упорядкована сукупність взаємопов'язаних компонентів, які повинні забезпечити виконання тих чи інших завдань, виконання тих чи інших функцій. При цьому, система передбачає наявність не тільки упорядкованості компонентів, які склалися відповідним чином, але і процесу їх взаємодії та функціонування.

У педагогічній літературі є розробки методик оцінювання результатів педагогічної діяльності викладача [12-15]. У багатьох наукових дослідженнях також розглядаються питання визначення рівнів підготовленості тих, хто навчається, за різними навчальними дисциплінами. Однак, ще недостатньо дослідженою $є$ проблема оцінювання рівня професійної компетентності викладача, зокрема викладача ВВН3, 3 позицій його професійно-методичних знань, навичок, умінь і необхідних особистісних якостей.

Заслуговує на увагу кваліметричний nidxid до оцінювання педагогічної кваліфікації викладача. Цей підхід базується на визначенні складових цієї системної характеристики викладача, діагностуванні та оцінюванні кожної складової, на підставі результатів яких виводиться інтегрований показник педагогічної кваліфікації викладача $[16,17]$.

Дослідники професійної компетентності викладача запропонували декілька систем оцінювання професійних якостей педагога на основі педагогічної кваліметрії [18-22]. Наприклад, В.П. Сімонов запропонував використовувати для визначення рівня професіоналізму викладача карту професійно-значимих особистісних якостей викладача у показниках, що діагностуються [23, с. 22-27]. Він виділив рівні характеристик якостей педагогів и групи критеріїв професіоналізму: 1-й рівень - риси особистості викладача як індивідуальності; 2-й рівень - викладач у структурі міжособистісних відносин; 3-й рівень - професійні риси особистості викладача; 4-й рівень - ефективність професійної діяльності викладача. 
Мета статті. Запропонувати алгоритм формування критеріїв оцінювання професіональної компетентності викладачів ВВНЗ з метою використання у системі вищої військової освіти та підвищення якості освітнього процесу.

Методи дослідження: Для розв'язання поставлених у статті завдань використано діяльнісний, компетентнісний та системний підходи, методи аналізу, синтезу, узагальнення та моделювання.

Виклад основного матеріалу. Дослідники діяльності викладачів вищої школи з точки зору вдосконалення педагогічної компетентності представляють компетентність як “системну властивість особистості", що створюється шляхом взаємодії та взаємопроникнення професійно-освітнього, професійнодіяльнісного та професійно-особистісного компонентів [24, 25].

Професійно-освітній компонент стосовно викладача ВНЗ є комплексом теоретичних знань, які забезпечують його професійну діяльність (як наукову, так і педагогічну). Глибокі теоретичні знання мають служити основою відповідних умінь, які є однією з умов ефективності практичної діяльності викладача.

Професійно-діяльнісний (практичний) компонент включає знання i вміння викладача, які отримані 3 досвіду власної професійної діяльності. Іншими словами, досвід самостійної практичної діяльності якраз і $є$ змістом професійно-деяльнісного компонента.

Професійно-особистісний компонент передбачає високий рівень розвитку якостей особистості викладача, які впливають на рівень організації та здійснення професійної діяльності.

У таких процедурах, як комплексне, системне оцінювання та визначення рівня професіоналізму викладача, на нашу думку, оптимальним $\epsilon$ створення структурної моделі педагогічної компетентності на основі еталонних критеріїв. У такому випадку можливі два підходи до формування еталонних критеріїв структурної моделі професійної компетентності викладача:

1. Якщо для оцінки професійної компетентності викладача використовувати як основні критерії результати його педагогічної діяльності, то має бути складена багаторівнева характеристика знань, умінь, навичок i вихованості тих, хто навчається.

2. Якщо основним критерієм професійної компетентності враховувати психолого-педагогічну підготовленість викладача, то необхідно охарактеризувати його професійні знання і уміння у цій сфері діяльності.

На нашу думку, при використанні системного підходу доцільним $\epsilon$ застосування обох варіантів формування еталонних критеріїв щодо створення адекватної моделі педагогічної компетентності, що досліджується.

При формуванні структурної моделі професійної компетентності викладача ВВНЗ передбачається виконати такі умови:

виділити та охарактеризувати якісні рівні професійних знань і умінь викладача;

розробити алгоритм оцінювання професійної компетентності викладача; 
вибрати способи фіксування, оброблення та узагальнення результатів експертної оцінки [26].

Оскільки модель професійної компетентності викладача ВВНЗ має складну структуру, то й система критеріїв, за допомогою яких здійснюватиметься оціночна характеристика цього педагогічного явища, також $\epsilon$ складним структурним утворенням.

Нині дослідники даної проблеми виділяють три групи критеріїв професійної компетентності викладача:

1. Критерії, які стосуються планування та організації педагогічної діяльності.

2. Критерії, які характеризують упровадження результатів наукових досліджень у педагогічну практику.

3. Критерії якості та успішності педагогічної діяльності.

Кожний критерій може бути представлений у вигляді рангової шкали, яка відображає рівень тої чи іншої якості, що характеризує професійну компетентність викладача. У рамках цієї проблеми розроблені концептуальні положення щодо оцінювання якостей викладача, обгрунтовані підходи вибору еталонних критеріїв [27].

У більшості досліджень утвердилися еталонні критерії оцінювання педагогічної діяльності, основу яких становлять професійна підготовленість, результативність педагогічного труда і особистісні якості викладача.

Базова професіограма викладача може включати три складові, які відображають якісні характеристики професійної компетентності педагога:

1. Кваліфікачія за навчальною дисиипліною. Викладачеві потрібні фундаментальні знання теорії своєї навчальної дисципліни, напрямів та змісту сучасних наукових досліджень у даній галузі науки, практичні уміння передавати знання з навчальної дисципліни тим, хто навчається.

2. Загальнопедагогічна кваліфікація. Викладачеві потрібні знання педагогічних принципів, технологій, методів и форм навчання, досвід їх запровадження в педагогічної практиці.

3. Методична кваліфікащія. Викладач повинен вміти на підставі заданого кінцевого результату проектувати процес навчання, використовувати в педагогічній практиці різноманітні форми і методи навчання для досягнення поставлених навчальних цілей, володіти ефективними методами організації самостійної роботи тих, хто навчається, бути чутливим до інновацій в організації навчального процесу [28].

Основою для побудови моделі професійної компетентності викладача також може служити структура професійних умінь викладача, яка запропонована B.A. Сластьоніним і створена 3 використанням системного підходу [29, с. 41-53]. Структура професійних умінь викладача включає такі складові:

I. Теоретична готовність викладача.

1.1. Аналітичні вміння: 
виділяти основні цілі педагогічної діяльності та забезпечувати їх досягнення;

структурувати педагогічні уявлення на складові елементи;

аналізувати окремі елементи педагогічного процесу і робити узагальнені висновки;

формувати на основі осмислення теорій навчання та виховання перспективні завдання щодо вдосконалення навчально-виховного процесу;

проектувати педагогічні процеси і впроваджувати інноваційні технології навчання.

\section{2. Прогностичні вміння:}

прогнозувати результати педагогічного впливу на тих, хто навчається; прогнозувати розвиток навчального колективу, зміни його структури i системи взаємовідносин у ньому;

прогнозувати особистісний розвиток тих, хто навчається.

\section{3. Проективні вміння:}

перетворювати цілі та зміст навчального процесу в конкретні педагогічні завдання;

визначати головні та другорядні завдання для кожного етапу педагогічного процесу;

враховувати потреби та інтереси тих, хто навчається, при визначенні педагогічних завдань;

вибирати методи і форми навчання, які $\epsilon$ адекватними відповідним педагогічним завданням;

планувати та організовувати індивідуальну роботу тих, хто навчається, 3 метою розвитку їхніх здібностей.

\section{4. Рефлексивні вміння:}

самопрогнозувати, самоаналізувати професійну діяльність, усвідомлювати особисту відповідальність за їі результати;

вивчати інших людей, співпереживати, орієнтуватися на інтереси інших;

змінювати уявлення про себе як про особистість і професіонала.

II. Практична готовність викладача.

2.1. Мобілізащійні вміння:

зосереджувати увагу тих, хто навчається, на навчальну дисципліну, розвивати в них інтерес до пізнавальної діяльності;

формувати потреби в інформації, отриманні знань, опануванні основами наукових досліджень;

активізувати пізнавальну діяльність тих, хто навчається, націлювати на досягнення позитивних результатів у навчанні.

2.2. Інформачуійні вміння:

викладати навчальний матеріал ясно, логічно і компетентно;

формувати навчальні питання, завдання для самостійної підготовки курсантів з метою глибокого засвоєння навчального матеріалу;

використовувати технічні засоби навчання; 
корегувати зміст навчальних планів і програм навчальних дисциплін у відповідності до нових завдань щодо підготовки фахівців з вищою освітою.

\section{3. Розвиваючі вміння:}

визначати перспективи професійного становлення окремих курсантів $\mathrm{i}$ навчальної групи;

використовувати в ході навчальних занять проблемні ситуації та інші форми активізації пізнавальних процесів;

стимулювати пізнавальну діяльність курсантів;

створювати психолого-педагогічні умови для розвитку індивідуальних здібностей курсантів.

\section{4. Ориєнтаиійні вміння:}

формувати у курсантів високі моральні цінності;

підтримувати у курсантів постійну мотивацію до активної навчальної роботи;

направляти пізнавальну діяльність курсантів.

\section{5. Периептивні вміння:}

сприймати й адекватно інтерпретувати інформацію, яка отримана від партнерів по спілкуванню та інших джерел;

визначати особистісну сутність інших осіб, тип їхньої особистості, темперамент та інші особистісні якості.

\section{6. Уміння педагогічного спілкування:}

встановити психологічний контакт з навчальною групою;

створити на навчальних заняттях обстановку колективного творчого пошуку;

впевненню діяти в публічної обстановці;

використовувати різноманітні педагогічні техніки.

Висновки та перспективи подальших досліджень. У наведеній структурі професійних умінь викладача відокремлені основні блоки професійної діяльності педагога и простежена єдина, взаємопов'язана система діяльнісних елементів. Даний підхід може бути використаний при оцінюванні професійної компетентності викладачів вищої школи, в тому числі BBH3.

3 метою здійснення якісної та кількісної оцінки професіоналізму викладача пропонується такий алгоритм формування критеріїв оцінювання:

формування цілі та педагогічних завдань оцінювання;

аналіз об'єкта (суб'єкта) дослідження, його основних показників i виділення серед них еталонних;

формування структури критерію;

визначення рангових коефіцієнтів еталонних показників та ранжування отриманих значень;

аналіз і узагальнення отриманих результатів дослідження [30, с. 7-8].

Необхідно також створити умови, які сприяють комплексному оцінюванню професійної компетентності викладача:

врахування усіх системних компонентів професійної компетентності; 
технологічність та мобільність процесу оцінювання;

високий рівень обгрунтованості.

Отже, системний підхід дозволяє розглядати професійну компетентність не як низку відповідних знань, умінь, навичок і якостей особистості викладача, а як складну структуру взаємовідносин і зв'язків елементів, які становлять еталонні критерії професіоналізму [31, с. 19-21].

Характеристика професіоналізму викладача ВВНЗ повинна містити досить повний перелік найбільш важливих критеріїв щодо якостей особистості викладача, змісту педагогічної діяльності та показників їі результативності [32]. Тому завданням нашого дослідження стало створення системно-структурних критеріїв, на основі яких можна 3 достатньою достовірністю визначати професійну компетентність викладача.

\section{ЛІТЕРАТУРА}

1. Азаров Ю.П. Искусство воспитывать. - М.: Педагогика, 1985. - 387 с.

2. Бабанский Ю.К. Оптимизация процесса обучения. Общедидактический аспект. M, 1977. - $415 \mathrm{c}$.

3. Грошева И.В. Модель системного отношения как основа профессиональной подготовки учителя // Прикладная психология. - 1999.- № 5. - С. 20-24.

4. Кузнецова А.Г. Системный подход в отечественной педагогике 60-х - 80-х годов XX века. - М., 2000. - 250 с.

5. Кузьмина Н.В. Способности, одаренность, талант учителя. - Л., 1985. - 216 с. $318 \mathrm{c}$.

6. Подласый И.П. Диагностика и экспертиза педагогических проектов. - К., 1998. -

7. Каган М.С. Система и структура. Системные исследования: методоло-гические проблемы. - М., 1993. - 436 с.

8. Афанасьєв В.Т. Системность и общество. - М., 1990. - 451 с.

9. Блауберг И.В., Юдин Э.Г. Становление и сущность системного подхода. - М.: Педагогика, 1983. - 417 с.

10. Бабанский Ю.К. О совершенствовании методов научно-педагогических исследований // Педагогика. - 1995. - № 1. - С. 63-75.

11. Кузьмина Н.В. Методы системного педагогического исследования: Учеб-ное пособие. - Л.: ЛГУ, 1980. - 172 с.

12. Абдуллина O.A. Педагогический мониторинг качества образования // Преподаватель. - 1998. - № 3. - С. 44-48.

13. Аттестация преподавателей и мастеров производственного обучения: Методическое пособие / Н.В. Кузьмина и др. - СПб., 1992. - 198 с.

14. Башарина Л.А. Педагогическая диагностика как условие совершенство-вания педагогического мастерства. - Автореферат дис... канд. пед. наук. - СПб., 1996. - 23 с.

15. Габдулахов P., Сайтов P. Аттестация педагогических кадров: процедура и критерии // Народное образование. - 2000. - № 7. - С. 78-84.

16. Ингеркамn K. Педагогическая діагностика / Пер. с немецкого. - М.: Педагогика, 1991. - $272 \mathrm{c}$.

17. Кухарев Н.В. На пути к профессиональному совершенству. - М., 1990. - 58 с.

18. Климин C., Красильников T. Автоматизированная система “Аттестация” служит делу // Народное образование. - 1994. - № 1. - С. 27-31.

19. Кондаков И.М. Экспериментальный анализ некоторых структурних осо-бенностей профессиональных интересов // Психологическая наука и обра-зование. - 1997. - № 1. C. 41-45.

20. Кьверялг A.A. Методы исследования в профессиональной педагогике. - Таллинн: Валгус, 1987. - 334 с. 
21. Методы системного педагогического исследования / Под ред. Н.В. Кузьминой. Л.: ЛГУ, 1980. - 217 с.

22. Силина С.Н. Профессиографический мониторинг в системе высшего образования педагога // Стандарты и мониторинг в образовании. - 1999. - № 2. - С. 26-29.

23. Симонов В.П. Аттестация преподавателей на диагностической основе // Специалист. - 1995. - № 9. - С. 23-27.

24. Маркова А.К. Психологические критерии и ступени профессионализма // Педагогика. - 1995. - № 6. - С. 55-63.

25. Лусс Е.Я. Актуальні проблеми педагогіки вищої військової школи. - Харків: ХВУ, 2001. $-423 \mathrm{c}$.

26. Хозяинов Г.И. Педагогическое мастерство преподавателя. - М.: Высшая школа, 1998. - $168 \mathrm{c}$.

27. Хорєв I.О. Дидактика вищої військової школи: Навчальний посібник. - К.: НАОУ, 2004. $-160 \mathrm{c}$.

28. Мизинцев В.П. Способ формализации и измерительная функция струк-турносистемных критериев // Педагогическое образование. - 1992. - № 5. - С. 63-67.

29. Профессиональная компетентность преподавателя вуза / Под ред. Н.Н. Лобановой. - СПб., 1994. - 524 с.

30. Структурно-системный подход в обучении и воспитании: Сборник научных трудов / Отв. редактор В.И. Ткачук. - Днепропетровск: ДГУ, 1984. - 321 с.

31. Педагогика / Под ред. В.А. Сластенина. - М.: Школа-Пресс, 1998. - 512 с.

32. Ваврик P.B. Структура професійної готовності викладачів ВВНЗ до педагогічної діяльності // Військова освіта: Зб. наук. праць. - 2003. - № 12. - С. 149-162.

Владимир Олиферук,

Национальный университет обороны Украины имени Ивана Черняховского, г. Киев

\section{Определение критеріев оценивания профессинальной компетентности преподавателя ВВУЗ}

В статье рассматривается проблема определения критериев оченивания профессиональной компетентности преподавателя высшего военного учебного заведения (дальше - ВВУЗ). Приводятся примеры формирования структуры критериев профессионализма преподавателя на основе профессиональнообразовательного, профессионально-деятельного и профессионально-личностного системных компонентов. Профессиональная компетентность преподавателя ВВУЗа представляется как сложная структура взаимоотношений и связей элементов, которые составляют эталонные критерии профессионализма.

Ключевые слова: критерии; педагогическая деятельность; преподаватель; профессиональная компетентность; высшее военное учебное заведение.

Vladimir Oliferuk,

National Defence University of Ukraine named after Ivan Cherniakhovskyi, c. Kyiv

\section{Determination of criteria for evaluating the professional competence of a teacher}

In the article the problem of the valuating criteria of the high military institute (HMI) instructor' professional competence define is considered. The examples for the structure of 
the instructor professionalism competence criteria forming on the base of professionaleducational, professional-active and professional-personal system components are given. The instructor' professional competence in HMI represented as a hard structure of relationships and connections of elements that the standard criteria of professionalism are.

Key words: criteria; pedagogical activity; instructor; professional competence; high military institute. 